J. Dairy Sci. 87:3076-3079

(c) American Dairy Science Association, 2004.

\section{Relationships Among International Body Condition Scoring Systems}

\author{
J. R. Roche, ${ }^{1}$ P. G. Dillon, ${ }^{2}$ C. R. Stockdale, ${ }^{3}$ \\ L. H. Baumgard, ${ }^{4}$ and M. J. VanBaale ${ }^{4}$ \\ ${ }^{1}$ Dexcel, Hamilton, New Zealand \\ ${ }^{2}$ Teagasc Moorepark, Fermoy, Co., Cork, Ireland \\ ${ }^{3}$ Primary Industries Research Victoria-Kyabram, \\ Kyabram, Victoria, Australia 3620 \\ ${ }^{4}$ Department of Animal Sciences, \\ The University of Arizona, Tucson 85721
}

\section{ABSTRACT}

Scoring body condition and assessing changes in the body condition of dairy cattle have become strategic tools in both farm management and research. Consequently, body condition score (BCS) is being researched extensively throughout the world. However, international sharing, comparing, and use of data generated are limited because different BCS systems exist. In the United States and Ireland a 5-point BCS system is used for dairy cows, whereas Australia and New Zealand use 8- and 10-point scales, respectively. The New Zealand 10-point scale was compared with the scoring systems in the United States, Ireland, and Australia by trained assessors. Cows were assessed visually in the United States and Australia, and in Ireland, cows were assessed by palpating key areas of the cow's body ( $\mathrm{n}=$ 154,110 , and 120, respectively). Data were analyzed by regression. Significant positive linear relationships were found between the New Zealand 10-point scale and the other scoring systems: US 5-point scale, $\mathrm{r}^{2}=$ 0.54; Irish 5-point scale, $\mathrm{r}^{2}=0.72$; and Australian 8point scale, $\mathrm{r}^{2}=0.61$. Those relationships must be interpreted cautiously because respective BCS within a given country were by just one experienced evaluator in each country in comparison to a separate evaluator scoring all cows in all counties using the New Zealand 10 -point scale. Also, few very thin or very fat cows limit evaluation across extremes of BCS. However, differences between systems were not accurately predicted by simple mathematical calculations. The relationship may be closer for New Zealand and Ireland $\left(r^{2}=0.72\right)$ because both of those scoring systems include palpation of individual body parts, whereas visual evaluation is done in Australia and the United States. The current

Received February 4, 2004.

Accepted April 8, 2004.

Corresponding author: J. R. Roche; e-mail: john.roche@ dexcel.co.nz. study is the first to examine relationships among differing BCS systems. These results may be useful for comparing/extrapolating research findings from different countries.

(Key words: body condition score, dairy cow)

\section{INTRODUCTION}

Managing body reserves is critical for successful cow management, and requires an accurate assessment of the cow's "condition." Until the 1970s, there was no simple measure of a cow's energy reserves or condition (Stockdale, 2001). Body weight alone was not a good indicator of body reserves, as cows of a specific weight may be tall and thin or short and fat. Andrew et al. (1994) and Gibb et al. (1992) found that energy stores varied by as much as $40 \%$ in cows of similar BW, highlighting the futility and inaccuracy of relying on BW alone as an index of cow condition. In addition, because tissue mobilization in early lactation occurs as feed intake is increasing, decreases in body tissue weight can be masked by enhanced gut fill, such that BW changes do not reflect changes in adipose and lean tissue weight (NRC, 2001).

Wright and Russel (1984) reported a strong positive relationship $\left(r^{2}=0.86\right)$ between BCS and the proportion of physically dissected fat in Friesian cows. Therefore, the visual or tactile (palpation) appraisal of cow condition or BCS provides a good assessment of body fat reserves, ignoring, or minimizing the influence of, frame size and intestinal contents.

Most animal and dairy scientists acknowledge successfully manipulating BCS as an important management factor, influencing animal health, milk production, and reproduction in the modern dairy cow (Domecq et al., 1997; Stockdale, 2001; Buckley et al., 2003). Traditionally, the period of most concern was at calving. Although BCS at breeding and the loss of BCS between parturition and the start of breeding, and the subsequent effect on reproduction, have gained considerable 
Table 1. Distribution of cow BCS (number of cows) assessed in the United States (USA), Ireland (IRE), and Australia (AUS) expressed on the 10-point BCS scale used in New Zealand (NZ).

\begin{tabular}{lccr}
\hline NZ BCS & $\begin{array}{l}\text { USA } \\
\text { cows }\end{array}$ & $\begin{array}{l}\text { IRE } \\
\text { cows }\end{array}$ & $\begin{array}{r}\text { AUS } \\
\text { cows }\end{array}$ \\
\hline 1 & 0 & 0 & 0 \\
2 & 0 & 0 & 13 \\
3 & 12 & 4 & 38 \\
4 & 34 & 35 & 28 \\
5 & 39 & 69 & 19 \\
6 & 53 & 12 & 12 \\
7 & 14 & 0 & 0 \\
8 & 1 & 0 & 0 \\
9 & 1 & 0 & 0 \\
10 & 0 & 0 & 0 \\
Total & 154 & 120 & 110 \\
\hline
\end{tabular}

attention in recent years (Beam and Butler, 1999; Buckley et al., 2003). Similarly, changes in BCS, as measured over several weeks, provide gross, but useful, information about the cow's current nutrient intake relative to its requirements.

The traditional subjective appraisal of body fat stores has been rationalized into numerical BCS systems, but there are many scales in use. In the United States and Ireland, 5-point scales are used (Wildman et al., 1982; Edmonson et al., 1989), whereas an 8-point scale is used in Australia (Earle, 1976), and New Zealand uses a 10-point scale (Macdonald and Macmillan, 1993; Macdonald and Roche, 2004). In all of the aforementioned scales, low values reflect emaciation and high values equate to obesity. Even though all systems evaluate between 5 and 8 separate body locations (Edmonson et al., 1989; DNRE, 2002; Macdonald and Roche, 2004), to date no attempt has been made to relate and compare these systems. This makes extrapolation and transfer of research findings between systems difficult and dependent on simple mathematical conversions. Relationships between the BCS systems used in the United States (Edmonson et al., 1989), Ireland (Wildman et al., 1982), and Australia (Earle, 1976), relative to the system used in New Zealand (Macdonald and Roche, 2004), are reported.

\section{MATERIALS AND METHODS}

In New Zealand and Ireland, BCS is assessed by palpating individual body parts, whereas in Australia and the United States the same body parts are visually evaluated. The anatomy considered most important include the thoracic and vertebral region of the spinal column (chine, loin, and rump), the ribs, the spinous processes (loin), the tuber sacrale (hip or hook bones), the tuber ischii (pin bones), the anterior coccygeal vertebrae (tail head), and the thigh region (Earle, 1976; Wildman et al., 1982; Macdonald and Roche, 2004).

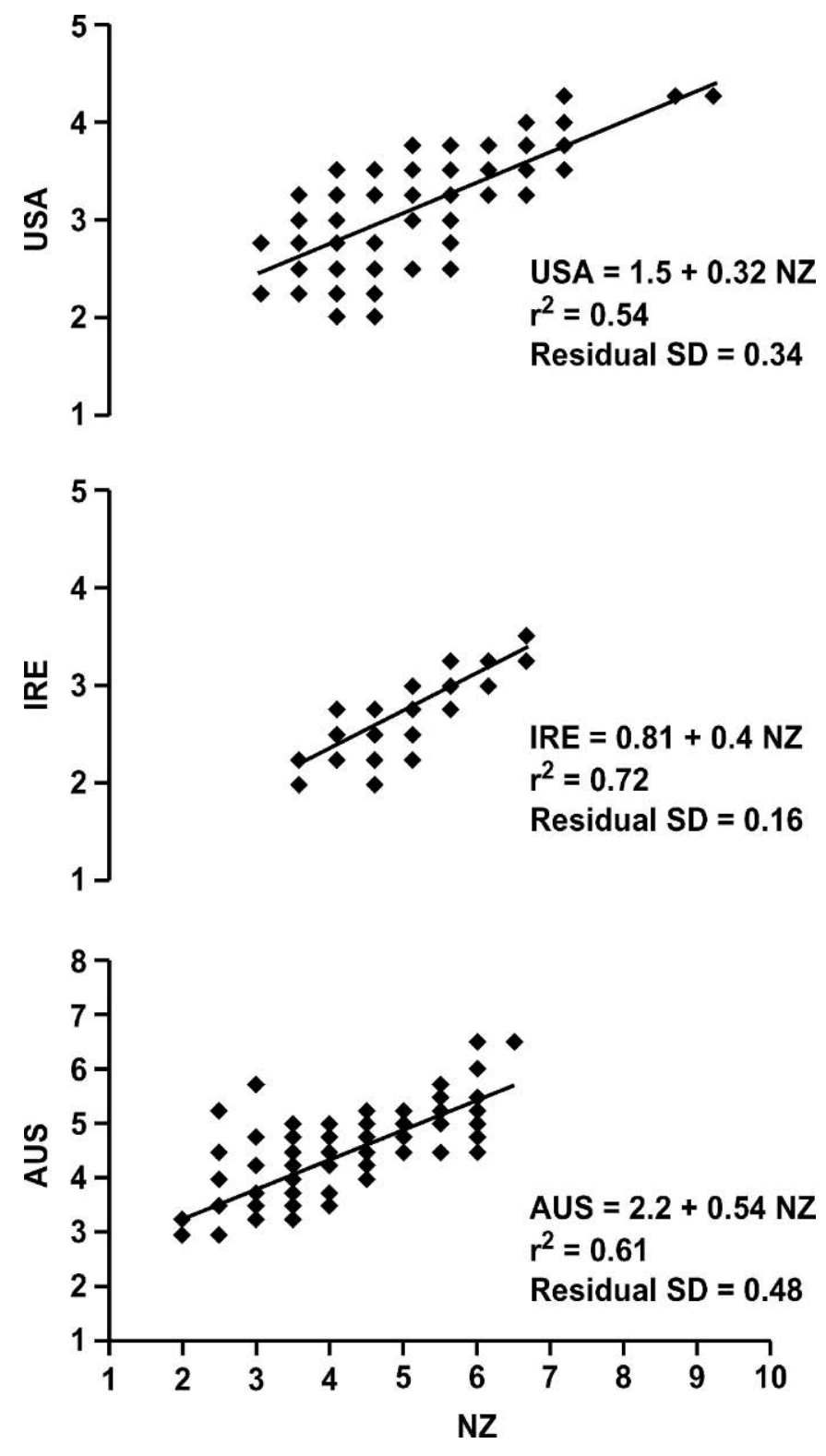

Figure 1. Relationship between the 10-point BCS scale used in New Zealand (NZ) and the 5-point BCS scale used in Ireland (IRE) and the United States (USA), and the 8-point BCS scale used in Australia (AUS). Each data point $(\bullet)$ represents multiple cows with identical BCS.

Between June and September 2003, 95 HolsteinFriesian and 49 Brown Swiss (early, mid, and late lactation) dairy cows in the United States (Tucson, AZ), 120 midlactation Holstein-Friesian dairy cows in Ireland (Moorepark, Co. Cork), and 110 dry/early lactating Holstein-Friesian dairy cows in Australia (Kyabram, Vic.) were independently assessed following the morning milking. The distribution in the BCS of the cows in each country using the 10-point scoring system of New Zealand is presented in Table 1. 
Within country, cows' individual BCS were appraised separately by one experienced evaluator in their own system and an assessor skilled in the 10-point New Zealand BCS system. Only the New Zealand evaluator participated in assigning BCS in each country.

Data were analyzed by linear regression using the statistical procedures of the Genstat V Committee (1997). Cows in the US sample were not separated into Holstein-Friesian and Brown Swiss because the procedure for assessing BCS should be standard across breeds (Macdonald and Roche, 2004).

\section{RESULTS AND DISCUSSION}

Having only one evaluator from each system is a limitation of this study. It was not possible, logistically speaking, to have several experienced evaluators present at each location. However, all evaluators had several years experience in assessing BCS in their respective systems, were educators in BCS in their respective systems, and were all scientists involved in BCS research in recent years. In addition, it has been reported that variability among cows has a much greater impact on the variance of scores than the variability among assessors (Edmonson et al., 1989).

Strong positive linear relationships $(P<0.001)$ were found (Figure 1) between the New Zealand 10-point BCS scale and the other scoring systems: US 5-point scale, $\mathrm{r}^{2}=0.54$; Irish 5-point scale, $\mathrm{r}^{2}=0.72$; and Australian 8-point scale, $r^{2}=0.61$. The correlation was weaker when scoring was visually based, which could mean that visual assessment places more or less emphasis on particular body parts than do systems involving palpation. This differs from the results reported by Edmonson et al. (1989), who reported that visual evaluation of BCS using charts was an effective method of assessment, and may suggest that for consistency between research trials, BCS should be assessed via palpation.

Interestingly, the 10-point scale is not simply a doubling of the 5-point scales (Table 2). For example, a BCS of 6.0 in the 10-point system is equivalent to 3.4 and 3.2 in the US and Irish scoring systems, respectively, or 56 and $53 \%$ of the 10-point evaluation. In comparison, a BCS of 2 in the 10-point system is equal to a 2.1 and 1.6 in the US and Irish systems, respectively. A similar convergence of numerical scores was apparent when the 10- and 8-point systems were compared. This may be influenced by the experience of the assessors in appraising thin animals. Additionally, differences in the distribution of BCS in the samples assessed may have influenced the slopes of the lines. Ideally, more emaciated and obese cows would have been included in the sample scored in each location. However, such cows were not available for assessment.
Table 2. Relationship ${ }^{1}$ between the 10-point BCS scale used in New Zealand (NZ) and the 5-point BCS scale used in Ireland (IRE) and the United States (USA), and the 8-point BCS scale used in Australia (AUS).

\begin{tabular}{llll}
\hline NZ & USA & IRE & AUS \\
\hline 1.0 & 1.82 & 1.21 & 2.74 \\
1.5 & 1.98 & 1.41 & 3.01 \\
2.0 & 2.14 & 1.61 & 3.28 \\
2.5 & 2.30 & 1.81 & 3.55 \\
3.0 & 2.46 & 2.01 & 3.82 \\
3.5 & 2.62 & 2.21 & 4.09 \\
4.0 & 2.78 & 2.41 & 4.36 \\
4.5 & 2.94 & 2.61 & 4.63 \\
5.0 & 3.10 & 2.81 & 4.90 \\
5.5 & 3.26 & 3.01 & 5.17 \\
6.0 & 3.42 & 3.21 & 5.44 \\
6.5 & 3.58 & 3.41 & 5.71 \\
7.0 & 3.74 & 3.61 & 5.98 \\
7.5 & 3.90 & 3.81 & 6.25 \\
8.0 & 4.06 & 4.01 & 6.52 \\
8.5 & 4.22 & 4.21 & 6.79 \\
9.0 & 4.38 & 4.41 & 7.06 \\
9.5 & 4.54 & 4.61 & 7.33 \\
10.0 & 4.70 & 4.81 & 7.60 \\
\hline
\end{tabular}

${ }^{1}$ Figures outside the range measured are extrapolated from the regression equations; $\mathrm{USA}=1.5+0.32 \mathrm{NZ}, \mathrm{IRE}=0.81+0.4 \mathrm{NZ}$, and $\mathrm{AUS}=2.2+0.54 \mathrm{NZ}$.

In general, the pasture-based system of dairy farming in New Zealand results in thinner cows than cows in the other 3 systems, resulting in a BCS classification that is probably more sensitive to BCS change at the lower end of the scale. This would also explain the lower predicted BCS in thin cows using the Irish equation compared with the US equation. This is an important observation because it means that simple numerical conversions of BCS from cows in pasture-based systems probably overemphasize the degree of emaciation of these animals. The reported equations should allow for more effective distribution and comparisons of international research results and improve the applicability of such data for producers.

\section{ACKNOWLEDGMENTS}

The authors acknowledge the assistance of J. Kay, K. Macdonald, D. Berry, C. Moore, H. Haflinger, O. Mediville, B. Dow, and all the help afforded by farm staff at The University of Arizona (USA), Curtin's Farm, Moorepark (Ireland) and Kyabram Dairy Centre (Australia). The financial contribution of Dexcel Ltd. is gratefully acknowledged.

\section{REFERENCES}

Andrew, S. M., D. R. Waldo, and R. A. Erdman. 1994. Direct analysis of body composition of dairy cows at three physiological stages. J. Dairy Sci. 77:3022-3033. 
Beam, S. W., and W. R. Butler. 1999. Effects of energy balance on follicular development and first ovulation in postpartum dairy cows. J. Reprod. Fertil. 54:411-424.

Buckley, F., K. O'Sullivan, J. F. Mee, R. D. Evans, and P. Dillon. 2003. Relationships among milk yield, body condition, cow weight, and reproduction in spring-calved Holstein-Friesians. J. Dairy Sci. 86:2308-2319.

DNRE. 2002. The Condition Magician. Body condition scoring in dairy herds. Department of Natural Resources and Environment, Victoria, Australia. ISBN 0731149831.

Domecq, J. J., A. L. Skidmore, J. W. Lloyd, and J. B. Kaneene. 1997. Relationships between body condition scores and conception at first artificial insemination in a large dairy herd of high yielding Holstein cows. J. Dairy Sci. 80:113-120.

Earle, D. F. 1976. A guide to scoring dairy cow condition. J. Agric. (Victoria) 74:228-231.

Edmonson, A. J., I. J. Lean, L. D. Weaver, T. Farver, and G. Webster. 1989. A body condition scoring chart for Holstein Dairy Cows. J. Dairy Sci. 72:68-78.

Genstat V Committee. 1997. Genstat 5, Release 4.1, Reference Manual. Oxford University Press, Oxford, United Kingdom.
Gibb, M. J., W. E. Irvings, M. S. Dhanoa, and J. D. Sutton. 1992. Changes in body components of autumn-calving Holstein Friesian cows over the first 29 weeks of lactation. Anim. Prod. 5:339-360.

Macdonald, K. A., and K. L. Macmillan. 1993. Condition score and liveweight in Jersey and Friesian cows. Pages 47-50 in Proc. 45th Ruakura Farmers Conference, Hamilton, New Zealand.

Macdonald, K. A., and J. R. Roche. 2004. Condition Scoring Made Easy. Condition Scoring Dairy Herds. 1st ed. Dexcel Ltd., Hamilton, New Zealand. ISBN 0-476-00217-6.

National Research Council. 2001. Pages 13-27 in Nutrient Requirements of Dairy Cattle. 7th rev. ed. Natl. Acad. Sci., Washington, DC.

Stockdale, C. R. 2001. Body condition at calving and the performance of dairy cows in early lactation under Australian conditions: A review. Aust. J. Exp. Agric. 41:823-829.

Wildman, E. E., G. M. Jones, P. E. Wagner, R. L. Boman, H. F. Troutt, Jr., and T. N. Lesch. 1982. A dairy cow body condition scoring system and its relationship to selected production characteristics. J. Dairy Sci. 65:495-501.

Wright, I. A., and A. J. F. Russel. 1984. Partition of fat, body composition and body condition score in mature cows. Anim. Prod. 38:23-32. 